\title{
IMPLEMENTASI PERCAMPURAN HARTA BERSAMA DAN HARTA BAWAAN DALAM PERKAWINAN (Studi Kasus Putusan Pengadilan Agama NOMOR : 0189/PDT.G/2017/PA.SMG)
}

\section{ARUN PRATAMA}

\begin{abstract}
ABSTRAK
Pada lembaga perkawinan masyarakat dikenal adanya pencampuran harta perkawinan, sehingga tidak menutup kemungkinan adanya percampuran harta bersama dan harta bawaan. Dalam hukum positif hanya mengatur mengenai harta bawaan dan harta bersama secara terpisah, tetapi tidak diatur mengenai percampuran harta bersama dan harta bawaan. Permasalahan yang dibahas dalam penelitian ini adalah ketentuan hukum mengenai percampuran harta bersama dan harta bawaan dalam perkawinan menurut UU Nomor 1 Tahun 1974 dan Kompilasi Hukum Islam (KHI) dan implementasinya dalam perkawinan setelah adanya perceraian pada putusan Pengadilan Agama Nomor : 0189/Pdt.G/2017/ PA.Smg.

Untuk melakukan penelitian menggunakan metode pendekatan yuridis normatif, sehingga data yang digunakan data sekunder. Adapun teknik pengumpulan data dilakukan melalui studi kepustakaan sedangkan teknik analisis data menggunakan analisis kualitatif.

Hasil penelitian menunjukkan bahwa ketentuan hukum mengenai percampuran harta bersama dan harta bawaan dalam perkawinan diatur dalam Pasal 35 Undang-Undang Nomor 1 Tahun 1974 tentang Perkawinan dan Pasal 1 huruf $\mathrm{f} \mathrm{KHI}$ yang pada intinya menyatakan bahwa bahwa harta benda yang diperoleh selama perkawinan menjadi harta bersama tanpa mempersoalkan terdaftar atas nama siapapun, meskipun di dalamnya terdapat harta bawaan. Implementasi percampuran harta bersama dan harta bawaan dalam perkawinan setelah adanya perceraian pada putusan Pengadilan Agama Nomor : 0189/Pdt.G/2017/PA.Smg adalah dalam hal pembagian harta bersama pihak istri mendapatkan bagian lebih besar dari pihak suami yaitu $3 / 4$ bagian sedangkan suami $1 / 4$ bagian. Hal tersebut mencerminkan keadilan distributif dimana hakim memberikan jatah kepada setiap orang berdasarkan jasanya atau memberikan kepada setiap orang apa yang menjadi haknya berdasarkan kepada azas keseimbangan atau memberikan hak kepada setiap orang berdasarkan prestasinya atau memberikan penghargaan kepada pihak yang berprestasi atau melindungi pihak yang berprestasi (pihak yang kuat).
\end{abstract}

Kata kunci : implementasi, percampuran, harta 


\title{
THE IMPLEMENTATION OF MIXING OF MARITAL AND INDIVIDUAL PROPERTY IN MARRIAGE (Case Study of Religious Court Decision NUMBER:0189/PDT.G/2017/PA.SMG)
}

\section{ARUN PRATAMA}

\begin{abstract}
In marriage institution, the society knows a mixing of marital property, there is possibility of mixing of marital and individual property. Positive law only regulates the possessions and joint property separately, but it is not regulated about the mixing of marital and individual property. The problem discussed in this research is legal provisions concerning the mixing of marital and individual property in marriage according to Law Number 1 Year 1974 and Compilation of Islamic Law (KHI) and its implementation in marriage after the divorce on Religious Court decision Number: 0189/Pdt.G/2017/PA.Smg.

This research used normative juridical approach method, data used were secondary data. The technique of data collection was done through literature study while the data analysis technique was done by using qualitative analysis.

The results showed that the legal provisions concerning the mixing of marital and individual property in marriage are regulated in Article 35 of Law Number 1 Year 1974 concerning Marriage and Article 1 letter $f \mathrm{KHI}$ which in essence states that the property acquired during marriage becomes joint property without the questioning the name of being registered on behalf of, even if there is individual property. The implementation of mixing of marital and individual property in marriage after divorce on Religious Court's decision Number: 0189/Pdt.G/2017/PA.Smg is in the case of division of property together the wife gets bigger part than the husband that is $3 / 4$ whereas husband is only $1 / 4$. It reflects distributive justice in which the judge gives each person a share according to his or her services, or gives each person her/his rights are based on the principle of equilibrium or entitles each person on the basis of his/her performance or rewards the achievers or protect the achiever (the strong party).
\end{abstract}

Keywords: implementation, mixing, property 


\section{PENDAHULUAN}

\section{A. Latar Belakang}

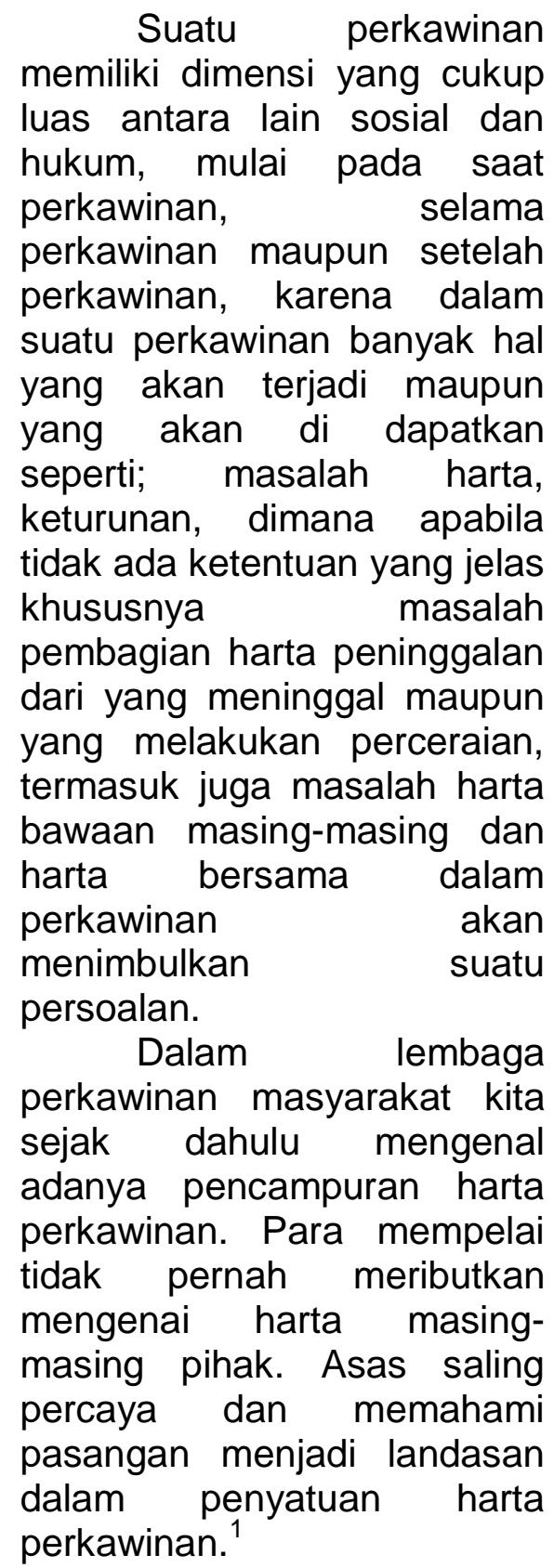

${ }^{1}$ Zulfiani, "Perlindungan Hukum terhadap Penguasaan Harta Bawaan dan Harta Bersama Setelah Perceraian Menurut UU No. 1 Tahun 1974 tentang Perkawinan Berbasis Keadilan", Jurnal Pembaharuan Hukum, Volume II No. 2 Mei - Agustus 2015, hlm. 357.
Dalam hal terjadi perceraian maka pembagian dari harta yang telah disyirkahkan meliputi modal awal dan hasil dari usaha tersebut. Apabila modal usaha tersebut berasal dari salah satu dari mereka maka modal tersebut harus dikembalikan kepada si pemilik. Sementara itu, menurut Undang-Undang Perkawinan Nomor 1 Tahun 1974, harta benda yang diperoleh selama perkawinan menjadi harta bersama dan apabila perkawinan putus karena perceraian harta bersama diatur menurut hukumnya masing-masing.

Penyelesaian harta bersama dalam perceraian menurut ketentuan Pasal 37 Undang-Undang Perkawinan yang menyatakan apabila perkawinan putus karena perceraian, harta bersama diatur menurut hukumnya masing-masing. Dalam penjelasan Pasal 37 UndangUndang Perkawinan, yang dimaksud dengan hukum masing-masing adalah hukum adat, agama, dan hukum lainnya. Sedangkan pada Pasal 97 Kompilasi Hukum Islam mengatur mengenai harta bersama, yaitu janda atau duda cerai masingmasing berhak seperdua dari harta bersama sepanjang tidak ditentukan lain dalam perjanjian perkawinan.

Pada kasus putusan Pengadilan Agama Semarang 
Nomor

0189/PDT.G/2017/PA.Smg, majelis hakim menetapkan dalam amar putusannya bahwa harta bersama dalam perkawinan dibagi menjadi $1 / 4$ bagian (25\%) untuk suami dan $3 / 4$ bagian (75\%) untuk istri. Putusan pengadilan mengenai pembagian harta bersama setelah perceraian tersebut lebih mempertimbangkan rasa keadilan yang dijadikan pertimbangan dalam menetapkan porsi bagian dari harta bersama mengingat adanya percampuran antara harta bersama dan harta bawaan dalam perkawinan.

Berdasarkan latar belakang tersebut di atas, penulis tertarik untuk melakukan penelitian tentang "IMPLEMENTASI

PERCAMPURAN HARTA BERSAMA DAN HARTA BAWAAN DALAM PERKAWINAN (Studi Kasus Putusan Pengadilan Agama Nomor

0189/Pdt.G/2017/Pa.Smg)"

\section{B. Perumusan Masalah}

1. Bagaimana ketentuan hukum mengenai percampuran harta bersama dan harta bawaan dalam perkawinan menurut UU Nomor 1 Tahun 1974 dan Kompilasi Hukum Islam (KHI)?

2. Bagaimana implementasi percampuran harta

$\begin{array}{lr}\text { bersama dan } & \text { harta } \\ \text { bawaan dalam } & \\ \text { perkawinan } & \text { setelah } \\ \text { adanya perceraian pada } \\ \text { putusan } & \text { Pengadilan } \\ \text { Agama } & \text { Nomor : } \\ \text { 0189/Pdt.G/2017/PA.Smg } \\ ?\end{array}$

\section{Metode Penelitian}

Metode pendekatan yang digunakan dalam penelitian ini adalah normatif, sehingga data yang digunakan adalah data sekunder. Metode pengumpulan data dilakukan melalui studi kepustakaan, sedangkan metode analisis data menggunakan analisis kualitatif.

\section{PEMBAHASAN}

A. Ketentuan Hukum Mengenai Percampuran Harta Bersama Dan Harta Bawaan Dalam Perkawinan Menurut Undang-Undang Nomor 1 Tahun 1974 Dan Kompilasi Hukum Islam (KHI)

Salah satu faktor yang penting dalam perkawinan adalah harta kekayaan yang dikatakan yang dapat menggerakkan suatu kehidupan perkawinan. Dalam perkawinan, memang selayaknyalah suami yang memberikan nafkah bagi kehidupan rumah tangga, dalam arti harta kekayaan dalam perkawinan ditentukan oleh kondisi dan tanggung jawab suami. Namun di zaman modern ini, dimana wanita telah hampir sama 
berkesempatannya dalam pergaulan sosial, wanita juga sering berperan dalam kehidupan ekonomi rumah tangga. Hal ini tentunya membawa pengaruh bagi harta kekayaan suatu perkawinan, baik selama perkawinan berlangsung maupun jika terjadi perceraian.

Pengaturan hukum mengenai harta bersama dalam hukum positif bersumber dari UU Perkawinan dan KHI. Sebagai contoh, jika pasangan suami istri ternyata bercerai, maka pembagian harta bersama mereka harus jelas didasari pada ketentuan-ketentuan yang berlaku dalam hukum positif tersebut.

Pengaturan mengenai harta bersama dalam UU Perkawinan diatur dalam Bab VII tentang harta bersama dalam perkawinan yang terdiri dari tiga pasal yakni pasal 35, 36 dan 37, sedangkan ketentuan hukum mengenai harta dalam Kompilasi Hukum Islam diatur dalam Bab XIII tentang harta benda dalam perkawinan, yaitu Pasal 85 s/d Pasal $95 \mathrm{KHI}$. Sedangkan ketentuan hukum mengenai harta bawaan dapat dijumpai dalam Pasal 35 ayat (2) Undang-Undang Nomor 1 Tahun 1974 tentang Perkawinan dan Pasal 36 ayat (2) UU Perkawinan. Harta bawaan juga diatur dalam Kompilasi Hukum Islam (KHI) yaitu pada Pasal 87. Terkait dengan pembagian harta bersama apabila terjadi perceraian diatur dalam Pasal $97 \mathrm{KHI}$ yang menjelaskan bahwa janda atau duda cerai masingmasing berhak seperdua dari harta bersama sepanjang tidak ditentukan lain dalam perjanjian perkawinan.

Berdasarkan

ketentuan pasal-pasal tersebut di atas, baik dalam UU Perkawinan maupun dalam $\mathrm{KHI}$ telah menentukan segala harta yang diperoleh selama perkawinan dengan sendirinya menurut hukum menjadi harta bersama. Adapun untuk menentukan apakah harta tersebut termasuk harta bersama atau bukan, Yahya Harahap memberikan penjelasan bahwa gambaran ruang lingkup harta bersama dalam suatu perkawinan, diantaranya adalah sebagai berikut : ${ }^{2}$

a. Harta yang dibeli selama perkawinan

b. Harta yang dibeli dan dibangun sesudah perceraian yang dibiayai dari harta bersama

\footnotetext{
${ }^{2}$ Yahya Harahap, Kedudukan Kewenangan Dan Acara Peradilan Agama, (Jakarta: Sinar Grafika, 2003), hlm. 275-278
} 


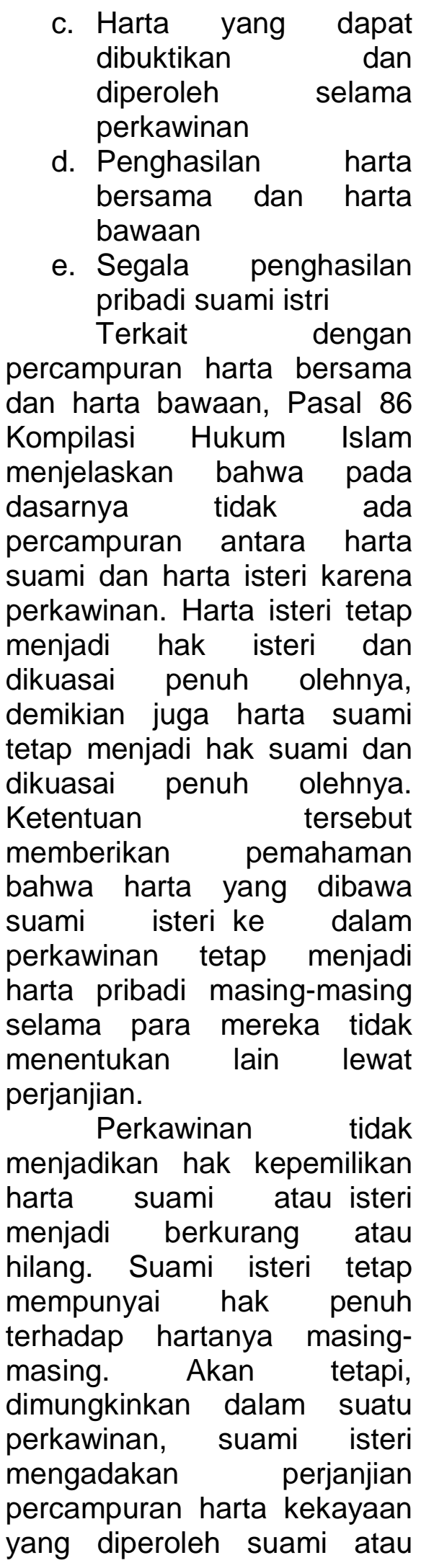

isteri selama dalam hubungan perkawinan atas usaha suami atau isteri sendiri-sendiri atau atas usaha bersama-sama. ${ }^{3}$

Dalam kasus terjadi
percampuran harta bawaan
dengan harta bersama,
misalnya harta bawaan telah
dijadikan sebagai modal
usaha bersama, maka apabila
terjadi perceraian harus
dipastikan nilai dari harta
bawaan tersebut. Jika memang dapat dibuktikan secara sah dan nilainya dapat dihitung secara pasti bahwa ada harta bawaan yang tercampur dalam harta bersama, maka harus diakui dan dipisahkan, sehingga harta bawaan tetap berada dalam penguasaan pemiliknya. Namun, jika pembuktian mengenai nilai harta bawaan sulit dilakukan, maka dapat dianggap sebagai harta bersama, karena harta tersebut dibeli/diperoleh ketika perkawinan

berlangsung.Terhadap

pasangan suami-istri yang tidak membuat perjanjian perkawinan pisah harta, harta bersama, harus dibagi dua sama rata antara suami dan istri. $^{4}$

\footnotetext{
${ }^{3}$ Konsekuensi Yuridis Harta Bersama terhadap Kewajiban Suami Memberi Nafkah Dalam Kompilasi Hukum Islam, (https://seowaps.wordpress.com, diakses 28 Desember 2017).

${ }^{4}$ Apakah Hasil Pengembangan Harta Bawaan menjadi Harta Gono Gini
} 
Sebagai ilustrasi pada putusan Pengadilan Agama Semarang Nomor : 0189/Pdt.G/2017/PA.Smg terjadi percampuran harta bersama dan harta bawaan. Harta bawaan dari pihak istri yaitu harta pemberian dari orang tuanya berupa uang sebesar Rp 1.500.000,- yang digunakan untuk membeli sebidang tanah seluas $120 \mathrm{~m}^{2}$ dan sejumlah Rp 20.000.000,yang digunakan untuk membangun rumah di atas sebidang tanah tersebut setelah terjadi pernikahan. Dalam hal ini, suami ikut andil dengan menjadi tukang dalam pembangunan rumah tersebut. Pada saat terjadi perceraian, pihak suami mengajukan gugatan yang pada pokoknya agar harta berupa tanah dan bangunan rumah tersebut ditetapkan sebagai harta bersama dan dibagi sama rata. Sedangkan pihak istri bersikukuh bahwa harta tersebut merupakan harta bawaan yang diperoleh dari orang tuanya, sehingga sudah selayaknya menjadi hak istri sepenuhnya.

$$
\text { Pada kasus tersebut, }
$$
hakim menetapkan bahwa harta yang menjadi objek sengketa tersebut merupakan harta bersama. Sebagai dasar hukum dalam menentukan harta bersama tersebut adalah Pasal 35 UndangUndang Nomor 1 Tahun 1974

?, http://www.hukumonline.com, diakses 10 Januari 2018.) tentang Perkawinan yang menyatakan bahwa harta benda yang diperoleh selama perkawinan menjadi harta bersama. Selain itu dalam Putusan MA No. 803K/SIP/197 juga menegaskan bahwa harta yang dibeli oleh suami atau istri di tempat yang jauh dari tempat tinggal mereka adalah termasuk harta bersama suami istri jika pembeliannya dilakukan selama perkawinan. Pada kasus tersebut, ketika terjadi perceraian hakim menetapkan pembagian harta bersama adalah $3 / 4$ bagian (75\%) menjadi milik istri dan $1 / 4$ bagian $(25 \%)$ bagian menjadi milik suami. Putusan tersebut menyimpang dari ketentuan Pasal 97 Kompilasi Hukum Islam menentukan bahwa janda atau duda cerai hidup masing-masing berhak mendapatkan seperdua dari harta bersama sepanjang tidak ditentukan lain dalam perjanjian perkawinan.

Berdasarkan ilustrasi tersebut diketahui, bahwa harta kekayaan yang dimiliki atau dibeli setelah terjadinya pernikahan, meskipun di dalamnya terdapat harta bawaan maka itu merupakan harta bersama. Hal ini dikarenakan pada kasus tersebut antara suami istri tidak membuat perjanjian perkawinan tentang pemisahan harta kekayaan, sehingga berlaku ketentuan 
Pasal 35 Undang-Undang Nomor 1 Tahun 1974 tentang Perkawinan yang menyatakan bahwa harta benda yang diperoleh selama perkawinan menjadi harta bersama. Namun terdapat pembatasan dimana untuk harta yang diperoleh setelah menikah yang bersumber dari hadiah, hibah dan waris tetap menjadi harta bawaan pihak yang bersangkutan. Sehingga sepenuhnya berada di bawah penguasaan masing-masing pihak.

\section{B. Implementasi Percampuran Harta Bersama dan Harta Bawaan dalam Perkawinan Setelah Adanya Perceraian Pada Putusan Pengadilan Agama Nomor 0189/Pdt.G/2017/Pa.Smg}

\section{Berdasarkan putusan PA Semarang} No.0189/Pdt.G/2017/PA.SMG di atas diketahui, bahwa telah terjadi percampuran harta bersama dan harta bawaan. Harta bawaan yang dimaksud adalah harta pemberian dari orang tua penggugat (istri) yaitu uang sebesar $\mathrm{Rp}$ 1.500.000,- yang digunakan untuk membeli sebidang tanah seluas $120 \mathrm{~m}^{2}$ dan sejumlah $R p$ 20.000.000,yang digunakan untuk membangun rumah di atas sebidang tanah tersebut. Pihak tergugat (suami) tidak ikut andil dalam pembiayaan pembelian tanah maupun pembangunan rumah, karena semua berasal dari harta yang diberikan oleh orang tua penggugat (istri). Meskipun demikian, tergugat (suami) ikut terlibat dalam membangun rumah, yaitu menjadi tukang dalam pembangunan rumah tersebut. Dalam hal ini, hakim menetapkan objek sengketa sebagai harta bersama.

Penetapan hakim mengenai harta bersama didasarkan pada ketentuan Pasal 35 Undang-Undang Nomor 1 Tahun 1974 tentang Perkawinan yang menyatakan bahwa harta benda yang diperoleh selama perkawinan menjadi harta bersama. Hal tersebut juga sesuai dengan ketentuan Putusan MA No. 803K/SIP/197, yang menegaskan bahwa harta yang dibeli oleh suami atau istri di tempat yang jauh dari tempat tinggal mereka adalah termasuk harta bersama suami istri jika pembeliannya dilakukan selama perkawinan. Demikian halnya pendapat Yahya Harahap yang menyatakan bahwa setiap barang yang dibeli selama ikatan perkawinan menjadi yurisdiksi harta bersama. Siapa yang membeli atas nama siapa terdaftar,dan dimana letaknya, tidak menjadi persoalan. Pada contoh kasus, pembelian tanah dan pembangunan rumah dilaksanakan setelah terjadinya perkawinan, dan 
antara suami istri tidak membuat perjanjian perkawinan, sehingga harta kekayaan yang diperoleh selama pernikahan adalah termasuk harta bersama. Dengan demikian, penetapan hakim mengenai harta bersama tersebut telah sesuai dengan kaidah hukum yang berlaku.

Permasalahan timbul terkait dengan pembagian harta bersama ketika antara suami istri terjadi perceraian. Pada putusan PA Semarang No.0189/Pdt.G/2017/PA.SMG , pihak suami menuntut agar harta bersama tersebut dibagi sama rata yaitu $1 / 2$ bagian untuk istri dan $1 / 2$ bagian untuk suami. Sesuai dengan ketentuan Pasal $97 \mathrm{KHI}$, janda atau duda cerai hidup masing-masing berhak mendapatkan $1 / 2$ bagian dari harta bersama. Namun demikian, dalam putusannya, hakim menetapkan bagian masing-masing dari harta bersama tersebut di atas adalah $1 / 4$ bagian (25\%) menjadi bagian suami sedangkan yang $3 / 4$ bagian $(75 \%)$ menjadi bagian istri. Menurut penulis, putusan hakim terkait dengan pembagian harta bersama tersebut telah sesuai dengan teori keadilan. Dalam menjalankan fungsi peradilannya, hakim harus memperhatikan keadilan, kepastian hukum, dan kemanfaatan. Putusan harus adil, mengandung kepastian hukum, tetapi putusan itu harus pula mengandung manfaat bagi yang bersangkutan dan masyarakat. Adil bagi satu pihak belum tentu dirasakan sama oleh pihak lainnya. Hakim harus memperhatikan pertimbangan hukum dengan baik dan teliti dalam menentukan proses suatu perkara, karena kualitas putusan hakim dapat dinilai dari bobot alasan dan pertimbangan hukum yang digunakan dalam memutus perkara.

Dalam pembuktian perkara perdata, yang hendak dicari hakim adalah kebenaran formil, yang berarti hakim terikat kepada keterangan atau alat bukti yang disampaikan oleh para pihak. Hakim terikat pada peristiwa yang diakui atau disengketakan. Di sini hakim cukup dengan pembuktian yang tidak meyakinkan. ${ }^{5}$ Akibat menekankan pembuktian formal, maka jika dalam proses persidangan obyek sengketa telah terbukti sebagai harta bersama akan dibagi suami isteri sama besar, pada hal belum tentu bahwa suatu harta yang secara formal adalah harta bersama tetapi secara

${ }^{5}$ Bambang Sutiyoso, Reformasi Keadilan Dan Penegakan Hukum Di Indonesia, (Yogyakarta: UII Press, 2010), hlm.131. 
material

sebenarnya

merupakan harta pribadi.

$$
\text { Penentuan harta }
$$

bersama dalam ikatan

perkawinan sangat penting untuk menetapkan bagian masing-masing suami istri atas harta tersebut apabila pasangan suami istri tidak lagi terikat dalam perkawinan karena perceraian. Dalam Kompilasi Hukum Islam Pasal 97 dijelaskan bahwa "janda atau duda cerai hidup masingmasing berhak seperdua dari harta bersama sepanjang tidak ditentukan lain dalam perjanjian perkawinan". Kalimat sepanjang tidak ditentukan lain dalam perkawinan menunjukkan bahwa ada ketentuanketentuan pembagian lain yang bukan dibagi dua melainkan ditentukan berdasarkan kesepakatan bersama sesuai dengan kondisi yang berpengaruh terhadap perolehan harta tersebut. $^{6}$

$$
\text { Menurut Satjipto }
$$

Rahardjo, hakim dalam memberikan rasa keadilan tidak semata-mata menggunakan kacamata preskriptif, yakni melihat hukum hanya sebagai sistem kaidah, eksemplar normologi yang penerapannya dicerabut

${ }^{6}$ Siah Khosyi'ah, Keadilan Distributif Atas Pembagian Harta Bersama Dalam Perkawinanbagi Keluarga Muslim Di Indonesia, Al Manahij, Vol. Xi No. 1, Juni 2017, hlm.41 dari akarnya. Padahal hukum itu bukan ilmu eksakta atau matrik. Di sinilah pengalaman hakim dapat diasah agar hakim tidak sekedar sebagai cerobong undang-undang. ${ }^{7}$

Putusan

No.0189/Pdt.G/2017/PA.SMG

telah memenuhi asas

keadilan. Majelis hakim

mempertimbangkan asal dari harta bersama tersebut, dimana dalam hal ini pihak istri memiliki andil yang cukup besar atas tanah dan bangunannya tersebut. Sehingga hakim berpendapat bahwa tidak adil apabila harta bersama tersebut dibagi sama rata. Harta bersama berupa tanah dan bangunan diatasnya dalam perkara tersebut secara formal memang adalah harta bersama tetapi secara material sebenarnya merupakan harta pribadi. Dengan demikian putusan hakim yang menetapkan $3 / 4$ bagian (75\%) untuk istri dan $1 / 4$ bagian (25\%) untuk suami tersebut telah memenuhi asas keadilan.

Majelis Hakim dalam menentukan pembagian harta bersama akibat perceraian dalam putusan No.0189/Pdt.G/2017/PA.SMG tidak sesuai dengan

\footnotetext{
${ }^{7}$ Satjipto Rahardjo, "Mahkota Hakim Dalam Lensa Pakar", Majalah Peradilan Agama, (Jakarta : Keluarga Besar Direktorat Jenderal badan Peradilan Agama Mahkamah Agung RI), hlm. 7.
} 
ketentuan Pasal $97 \mathrm{KHI}$ yang menyatakan bahwa janda atau duda cerai masingmasing berhak seperdua dari harta bersama sepanjang tidak ditentukan lain dalam perjanjian perkawinan. Namun, putusan tersebut telah mencerminkan rasa keadilan.

Sikap hakim secara hukum dapat dibenarkan karena hakim memiliki kebebasan dalam memutus dan memiliki hak otonomi dalam konsep "demi keadilan" untuk melakukan contra legem (menyimpang) terhadap pasal-pasal yang dirasa tidak sesuai dengan rasa keadilan dan kebenaran. Sebagaimana ditegaskan dalam Pasal 229 Kompilasi Hukum Islam yang menyatakan hakim dalam menyelesaikan perkaraperkara yang diajukan kepadanya wajib memperhatikan dengan sungguh-sungguh nilai-nilai hukum yang hidup di masyarakat, sehingga putusannya sesuai dengan rasa keadilan. Ketentuan pasal tersebut secara tegas menunjukkan suatu kemutlakan yang bersifat memaksa bagi hakim untuk memegang teguh dan menjadikan pasal tersebut sebagai landasan moral dalam menjatuhkan putusan. Hal ini juga sesuai dengan amanat Pasal 28 ayat 1 Undang-Undang No. 4 Tahun
2004 yang menyatakan bahwa "Hakim wajib menggali, mengikuti dan memahami nilai-nilai hukum dan rasa keadilan yang hidup dalam masyarakat".

Putusan

No.0189/Pdt.G/2017/PA.SMG menurut penulis juga telah memenuhi asas kepastian hukum. Kepastian hukum juga merupakan tujuan dari setiap undang-undang. Kepastian hukum akan tercapai apabila kata dan kalimat undangundang tersusun sedemikian jelasnya sehingga tidak menimbulkan penafsiran yang berbeda-beda. Kepastian hukum memiliki kaitan erat dengan penegakan hukum. Penegakan hukum itu sendiri merupakan suatu proses untuk mewujudkan keinginankeinginan hukum menjadi kenyataan. $^{8}$

Berdasarkan hasil

pemeriksaan dan pertimbangan Majelis Hakim, dalam hal ini menurut penulis telah memenuhi asas kepastian hukum, dimana putuuan mengandung autotorif yaitu memberikan jalan keluar untuk menciptakan stabilitas rasa tertib dan ketentraman masyarakat. Dalam proses persidangan,hakim telah memberikan kesempatan yang sama kepada para pihak untuk membuktikan dalil-dalil

\footnotetext{
${ }^{8}$ Abdul Rachmad Budiono,
}

Pengantar IImu Hukum, (Malang:

Bayumedia Publishing, 2005), hlm. 22. 
gugatan

maupun

bantahannya.

Pada

putusan

No.0189/Pdt.G/2017/PA.SMG

majelis hakim telah

melakukan pemeriksaan

setempat dan di lapangan

mengenai harta yang

disengketakan dan

menetapkan bahwa harta

tersebut merupakan harta

bersama. Dasar hukum yang

menjadi dalam pertimbangan

hakim yaitu ketentuan hukum harta bersama menurut Pasal 35 ayat (1) Undang-Undang Nomor 1 Tahun 1974 tentang Perkawinan jo pasal 1 huruf (f) Kompilasi Hukum Islam yang menyatakan bahwa harta benda yang diperoleh selama perkawinan menjadi harta bersama tanpa mempersoalkan atas nama siapa harta bersama itu terdaftar.

Dengan adanya penetapan harta bersama tersebut, maka harta tersebut mempunyai kepastian dan kekuatan hukum, sehingga harta tersebut tidak boleh diganggu gugat oleh pihak lain kecuali dengan persetujuan bersama antara suami istri. Putusan dalam perkara tersebut telah sesuai dengan tujuan undangundang yang dijadikan dasar yaitu kepastian dalam hukum itu sendiri dan kepastian karena hukum. Kepastian oleh hukum itu sendiri, yaitu putusan dalam perkara tersebut tidak mengandung kalimat yang multitafsir artinya jelas dan mudah dipahami oleh para pihak. Sementara terkait dengan kepastian karena hukum, dalam hal ini para pihak secara sukarela taat dan patuh terhadap putusan yang dijatuhkan oleh Majelis Hakim.

\section{PENUTUP}

\section{A. Simpulan}

1. Ketentuan mengenai

hukum harta bersama dan harta bawaan dalam perkawinan menurut Undang-Undang Nomor 1 Tahun 1974 dan Kompilasi Hukum Islam (KHI) adalah bahwa harta kekayaan yang dimiliki atau dibeli setelah terjadinya pernikahan, meskipun di dalamnya terdapat harta bawaan maka itu merupakan harta bersama. hal ini didasarkan pada ketentuan Pasal 35 Undang-Undang Nomor 1 Tahun 1974 tentang Perkawinan dan Pasal 1 huruf $f \mathrm{KHI}$ yang pada intinya menyatakan bahwa bahwa harta benda yang diperoleh selama perkawinan menjadi harta bersama tanpa mempersoalkan terdaftar atas nama siapapun. Namun dalam hal terjadi perceraian maka pembagiannya pun akan disesuaikan dengan asal harta bersama tersebut. 
2. Implementasi

percampuran harta bersama dan harta bawaan dalam perkawinan setelah adanya perceraian pada putusan Pengadilan Agama Nomor : 0189/Pdt.G/2017/PA.Smg adalah dalam hal pembagian harta bersama pihak istri mendapatkan bagian lebih besar dari pihak suami yaitu $3 / 4$ bagian sedangkan suami $1 / 4$ bagian. Hal tersebut mencerminkan keadilan distributif dimana hakim memberikan jatah kepada setiap orang berdasarkan jasanya atau memberikan kepada setiap orang apa yang menjadi haknya berdasarkan kepada azas keseimbangan atau memberikan hak kepada setiap orang berdasarkan prestasinya atau memberikan penghargaan kepada pihak yang berprestasi atau melindungi pihak yang berprestasi (pihak yang kuat).

\section{B. Saran}

1. Bagi hakim, hendaknya dalam memutus suatu perkara yang ditanganinya benarbenar memperhatikan substansi perkara tersebut dan lebih mengutamakan nilai keadilan.
2. Bagi pemerintah, perlu adanya sosialisasi mengenai harta bersama dan pengadilan agama untuk meningkatkan kesadaran hukum masyarakat.

3. Bagi masyarakat, hendaknya dalam penyelesaian sengketa pembagian harta bersama akibat perceraian hendaklah diselesaikan dengan cara kekeluargaan lebih dahulu, sebelum menempuh

penyelesaian di Pengadilan Agama.

\section{DAFTAR PUSTAKA}

\section{Buku-buku}

Harahap, Yahya. Kedudukan Kewenangan Dan Acara Peradilan Agama, Jakarta: Sinar Grafika, 2003.

Budiono, Abdul Rachmad. Pengantar IImu Hukum, Malang : Bayumedia Publishing, 2005.

Satjipto Rahardjo, "Mahkota Hakim Dalam Lensa Pakar", Majalah Peradilan Agama, (Jakarta : Keluarga Besar Direktorat Jenderal badan Peradilan Agama Mahkamah Agung RI).

Sutiyoso, Bambang. Reformasi Keadilan Dan Penegakan 
Hukum Di Indonesia, Yogyakarta: UII Press, 2010.

\section{Peraturan undangan \\ Undang-Undang Nomor 1 Tahun 1974 tentang Perkawinan. \\ Kompilasi Hukum Islam}

\section{Jurnal}

Siah Khosyi'ah, Keadilan Distributif Atas Pembagian Harta Bersama Dalam Perkawinanbagi Keluarga Muslim Di Indonesia, Al Manahij, Vol. Xi No. 1, Juni 2017.

Zulfiani, "Perlindungan Hukum terhadap Penguasaan Harta Bawaan dan Harta Bersama Setelah Perceraian Menurut UU No. 1 Tahun 1974 tentang Perkawinan Berbasis Keadilan", Jurnal Pembaharuan Hukum, Volume II No. 2 Mei Agustus 2015.

\section{Website}

$$
\begin{aligned}
& \text { Konsekuensi Yuridis Harta } \\
& \text { Bersama terhadap } \\
& \text { Kewajiban Suami Memberi } \\
& \text { Nafkah Dalam Kompilasi } \\
& \text { Hukum Islam, } \\
& \text { (https://seowaps.wordpress. }
\end{aligned}
$$

\section{Apakah Hasil Pengembangan Harta Bawaan menjadi}

Harta Gono Gini ?, http://www.hukumonline.co $\mathrm{m}$, diakses 10 Januari 2018.) 